\title{
MANAGEMENT ACCOUNTANTS' PROFESSIONAL COMPETENCES: REQUIREMENTS IN THE CZECH REPUBLIC AND POLAND. THE NORMATIVE APPROACH AND BUSINESS PRACTICE
}

\author{
Bohumil Král ${ }^{1}$, Grzegorz Mikołajewicz², Jarosław Nowicki², Libuše Šoljaková1 \\ ${ }^{1}$ Department of Management Accounting, Prague University of Economics and Business, Nám. W. Churchilla 4, \\ 13067 Prague, Czech Republic \\ ${ }^{2}$ Department of Controlling, Financial Analysis and Valuation, Poznań University of Economics and Business, \\ Al. Niepodległości 10, 61-875 Poznań, Poland
}

Link to this article: https://doi.org/10.11118/actaun.2021.035

Received: 18. 6. 2020, Accepted: 10. 5. 2021

To cite this article: KRÁL BOHUMIL, MIKOŁAJEWICZ GRZEGORZ, NOWICKI JAROSŁAW, ŠOLJAKOVÁ LIBUŠE. 2021. Management Accountants' Professional Competences: Requirements In the Czech Republic and Poland. The Normative Approach and Business Practice. Acta Universitatis Agriculturae et Silviculturae Mendelianae Brunensis, 69(3): 379-393.

\begin{abstract}
The aim of this paper is to ascertain, from the normative ("should be" - academic experts) and business practice ("is" - management accountants) perspective, whether and to what extent management accountants' competence requirements differ between the Czech Republic and Poland and if so, to indicate the reasons for such differences. Both groups of respondents, as well as both countries have they own specific characteristics, but also share some common qualities. All respondents emphasize an important role that management accountants play in modern companies and suggest the necessity of developing standards and requirements for this position. The study is unique, since it compares different perspectives of management accountants' professional competences expected by academic and business practice in two neighbouring countries (the Czech Republic and Poland) with their own specific institutional environment.
\end{abstract}

Keywords: management accountant, controller, professional competence, education, skills, experience, quality assurance

\section{INTRODUCTION}

Companies operate in turbulent environments which impact upon business management. Changes in company management manifest themselves in various ways and influence not only management instruments, but also methods and information support. Changes also impact upon the professional development of company management (Král and Šoljaková, 2015), including various aspects of the management accountants' work. Management accountants are becoming increasingly business-oriented and contributing more to value creation (Burns and Bladwinsottirs, 2005; Goretzki, Strauss and Weber, 2013; Järvenpää, 2017). Hence, whilst companies are formulating new requirements regarding management accountants' work and training, business schools and professional organizations have the role of implementing those requirements into curricula and certification systems.

This paper builds upon empirical studies devoted to the recent situation in the Czech 
Republic (Král and Šoljaková, 2016) and Poland (Král, Mikołajewicz, Nowicki and Šoljaková, 2017). The main goal is to examine and compare the management accountants' professional competences requirements in the Czech Republic and Poland from the normative and business practice point of view. Both countries - due to their recent common history - not only share many similarities regarding company management and its information support, but also exhibit many differences regarding their long-term cultural and economic development.

This paper is organised as follows. First there is a literature review to provide the broader context of the conducted research. The second section is devoted to research design and methodology. Thirdly, the empirical results are presented for the chosen areas, followed by a discussion. Our conclusions summarise the main research findings.

\section{Literature Review}

The topic discussed in the article is important not only from the controlling perspective but also in a broader context.

A turbulent business environment raises the bar for the proper management of a company (Burns and Yazdifar, 2001; Kaplan and Anderson, 2007; Marciniak, 2008; Sierpińska and Niedbała, 2003).

An increasing role for management accountants in the decision-making process is crucial to the development of companies because correct decision-making is fundamental to companies' competitive advantage (Chartered Institute of Management Accountants, 2008 and 2009). In this regard, it is important to train management accountants who will be able to enhance decisionmaking and support managers.

Zralý (2007) analyses the relations between managers and management accountants and proposes a format for their mutual collaboration called the 'controlling convergent concept'.

Grandlund and Lukka (1998) see the role of the management accountant not only as a provider of information support, but rather as the manager's partner. The perception of the management accountant as the manager's partner in the process of formulating and implementing strategies is gaining weight in the literature (Jaruga, Nowak and Szychta, 1999; Steinke, Schulze, Berlin, Stehle and Georg, 2014; Sierpińska and Niedbała, 2003), although particular requirements, their position in the organizational structure and the perception of a management accountant's tasks may vary between companies and countries (Bieńkowska, Kral and Zabłocka-Kluczka, 2014; Foremna-Pilarska, 2015; Janczyk-Strzała, 2008; Janik and Paździor, 2012; Kes, 2013; Marciniak, 2008; Szychta, 2011).

Changes in the content of management accountants' work have altered the requirements for their professional competences. In the past, work in controlling required thorough knowledge, skills and experience in management accounting instruments and methods, accompanied by the ability to make use of them in the company's information systems. Nowadays, management accountants' work is more interdisciplinary and their knowledge, skills and experience should help to combine management accounting data with nonfinancial information. Management accountants should be able to justify, interpret and present the results of the company and its parts, to provide quality information support to the decision-making process and to strengthen synergies based on the relations they develop (Burns and Yazdifar, 2001; Hopper, 1980; Horváth, 2006; Marciniak, 2008; Sierpińska and Niedbała, 2003; Yasin, Bayes and Czuchry, 2005; Zralý, 2007).

Furthermore, the increasing role of 'soft' skills can be noted in management accountants' work (Grandlund and Lukka, 1998; Jablonsky, Keating and Heian, 2004; Pierce and O'Deam, 2003; Yasin et al., 2005). This gives rise to the investigation of specific features of management accountants' characteristics, such as psychological and gender issues (Gmińska, 2014; Nowak, 2013, 2014a, 2014b).

What is a relatively new issue is the necessity to perceive, support and communicate ethical and moral values, approaches and attitudes (Grandlund and Lukka, 1998; Jablonsky et al., 2004; Pierce and O'Deam, 2003; Yasin et al., 2005), issues hitherto underplayed both in theory and in the practice of management accountants' professional competence development.

\section{MATERIALS AND METHODS}

In order to examine the requirements for professional competence development of management accountants, two groups of respondents were addressed in Czech Republic and Poland:

1. experts originating from business schools, universities etc. (the normative approach - "a management accountant should be" questionnaire), and

2. management accountants and managers operating in companies (the business reality perspective - "a management accountant is" questionnaire). Both versions of the questionnaire are very similar regarding their structure and content. Most of the questions used five-level Likert scale with answers scaled from 1 (strong disagreement) to 5 (strong agreement). Limited part of the questions required Yes or No or open answers.

Questionnaires referred to such issues as position of management accountants in the organization, structure of controlling departments, relation of these departments to other financial management departments, content of the management accountants' activities, authority and responsibility 
of management accountants, requirements for training, ICT competencies, professional skills and practical experience, management accountants' role in ethical aspects of business, continuous professional development (human resources management), as well as quality assurance of the management accountants' work. Continuous project development has yielded an increasing number of completed questionnaires. At the current stage of the project, the empirical returns are as follows:

- number of collected and completed 'A management accountant should be ...' questionnaires: 27 for the Czech Republic and 25 for Poland;

- number of collected and completed 'A management accountant is ...' questionnaires: 74 for the Czech Republic and 24 for Poland.

The number of questionnaires differs due to willingness to fill in questionnaires in both countries. The empirical research is still ongoing, but the outcomes thus far are of sufficient interest to warrant publication.

This project utilized various methods (Král and Šoljaková, 2014, 2016). In addition to comparison, we also applied descriptive and statistical methods, synthesis and analysis, analogy and generalization:

- descriptive methods were used to define the requirements for management accountants' professional competence development;

- during the questionnaire development (when considering the aims, content and structure of the questionnaire) methods of synthesis and analysis were used, as well as analogy, especially in the parts dedicated to education, skills and practical experience requirements for management accountants;

- comparisons were carried out during the research design as well as in empirical phase of the investigation;

- statistical methods were used to describe trends and relations in the empirical element as well as to present statistical inference; besides descriptive statistics, the Shapiro-Wilk normality test was used to examine whether the data was gleaned from a normally distributed population and the Mann-Whitney $U$ test was used to ascertain whether any differences between the opinions of the groups of experts and countries are statistically significant; descriptive statistics and detailed results of the Mann-Whitney $U$ test are presented in the Appendix;

- generalization was used in the phase of formulation the principal project outcomes.

All the above methods constitute a system approach. The respondents from the "Should be" group in Czech Republic are members of financial accounting, management accounting, corporate finance and strategy departments of the following Czech universities and business schools: Prague University of Economics and Business, Tomas Bata
University in Zlín, Czech Technical University, Prague, University of West Bohemia in Plzeň, Moravian College Olomouc and Masarykova University Brno.

The respondents from the "Should be" in Poland group are members of accounting, controlling and finance departments at Polish business university centres, i.e.: Cracow University of Economics, Nicolaus Copernicus University in Toruń, Poznań University of Economics and Business, SGH Warsaw School of Economics, University of Economics in Katowice, University of Gdansk, University of Lodz, University of Szczecin and Wrocław University of Economics.

The respondents in the "Is" group have been management accountants or managers of randomly selected Czech (Polish) as well as foreign companies operating in various industries in Czech Republic (Poland), i.e. insurance, banking, medical care, automotive, construction, FMCG, retail, passenger transport, logistics, alcohol, tobacco, marketing, machine producers, furniture manufacturing, water supply, metallurgical and chemical industry:

- $22 \%$ (46\% in Poland) of companies in the sample have assets exceeding €20m, 42\% (38\%) between $€ 2-20 \mathrm{~m}$ and the rest less than €2m;

- over $62 \%$ (58\%) of the companies have a turnover less than $€ 40 \mathrm{~m}$ and two groups of companies, sales between €40-400m and over €400m, reached the same share of 19\% (21\%) each;

- according to the employment, nearly 38\% (42\%) of companies have number of employees exceeding 500, ca. 45\% (38\%) between 50-500 and ca. $17 \%$ (20\%) less than 50;

- concerning ownership - 32\% (46\%) of them are part of concern, 31\% (21\%) owned by state or municipality and 37\% (33\%) have individual owners;

- the respondents have been working on the position for less than 10 years (48\%/58.5\%), 1020 years (38\%/29\%), $21-30$ years $(9 \% / 4 \%)$ and more than 30 years (5\%/8.5\%);

- a little more than half of them (52\%/58\%) are men.

The data collected from responses of both groups in Czech Republic and in Poland are analysed and discussed in subsequent sections of the paper.

\section{RESULTS}

\section{Management Accountants' Position in the Companies' Organizational Charts}

The responses referring to the position of management accountants in the organizational chart, the structure of the management accounting department and its mutual relations with other financial departments in the company, are ambiguous.

Nevertheless, most of the answers from both the Czech Republic and Poland indicate that management accountants and their departments: 
- are/should be supervised by the company CFO or directly by CEO (more in Poland);

- should be situated in the organizational structure at the same or a higher level than the accounting department;

- should render relevant advisory data to senior managers.

Those findings are in line with the understanding of management accountants as 'the economic conscience of a company' (Horváth, 2006). This also confirms the changes from traditional "bean counters" to "business partner".

\section{General Content of Management Accountants' Activities}

The results referring to the general content of management accountants' activities are very similar for all groups of experts from the Czech Republic and Poland regarding the assessment of the importance of individual activities. Management accountants are responsible for the quality, availability and transparency of the data provided and transferred to managers, as well as the correctness of input data processed subsequently into the output information used in managerial control; however, there is little difference between the opinions of experts from the two countries. The correctness of input data is slightly less important for experts from Poland, resulting in a higher reading for the second group of experts ('Is') than for the first ('Should be'), but the difference between opinions in Poland and the Czech Republic is statistically significant at 10 per cent only for the 'Should be' group ( $\mathrm{p}=0.0711$ ). Polish experts from the 'Is' group attach slightly higher importance to the availability and transparency of information than respondents from the Czech Republic. The difference is statistically significant at 10 per cent for availability $(p=0.0761)$ and at 1 per cent for the transparency of information ( $p=0.0013$ ).

What is significant and consistent with the above role of a management accountant as the economic conscience of the company' is that all groups of experts pointed out that a management accountant should not be and is not responsible for the company's financial results. The outcomes for the 'Is' group show a slightly higher average but the difference between these groups is statistically significant only for the Czech Republic ( $p=0.0096$ ). These results could, possibly, mean that the first group of experts generally rejects a responsibility for financial results, but in practice, management accountants are paid partly-based on financial results.

In our opinion, one possible explanation for this difference may be the fact that in many companies the remuneration system is linked with financial results to better motivate the employees in order to achieve the desired financial goals, regardless of whether or not those thus motivated have a direct impact on the financial results. This also applies to management accountants.

The exact results of this aspect of the study are shown in Tab. I.

\section{Management Accountants' Authority and Responsibility}

As far as the next part of the research is concerned, all the experts indicate that a management accountant is/should be equipped with sufficient authority and responsibility in the areas in which he/she serves as a communicator, developer and expert in communication, coordination and scenario analysis, as well as a specialist who participates in the regulation and support of the company's financial management development including the system of remuneration and motivation; however, Polish management accountants (from the "Is" group) gave higher scores - the difference is statistically significant at 5 per cent $(\mathrm{p}=0.0213)$.

What is worth noting is that in some areas the opinions of both groups of experts from Poland and the Czech Republic differ. The first area with varying opinions is the coordination of activities connected with the formulation of the company's objectives and the means for their fulfilment. According to the first group of experts both in Poland and the Czech Republic, management accountants should play an important role in this area, whereas the second group claims that in practice the role of management accountants is not

I: General content of management accountants' activities

\begin{tabular}{|c|c|c|c|c|}
\hline \multirow{2}{*}{ Description } & \multicolumn{2}{|c|}{ 'Should be' } & \multicolumn{2}{|c|}{ 'Is' } \\
\hline & $\mathrm{CZK}$ & PL & $\mathrm{CZK}$ & PL \\
\hline $\begin{array}{l}\text { Correctness of data processed subsequently into the output information used } \\
\text { in managerial control }\end{array}$ & 3.92 & 3.36 & 4.46 & 4.04 \\
\hline Quality of information rendered to company management & 4.46 & 4.36 & 4.26 & 4.58 \\
\hline Availability of information for company management & 4.13 & 4.20 & 3.94 & 4.42 \\
\hline Transparency of information rendered to company management & 4.54 & 4.44 & 4.12 & 4.71 \\
\hline Financial results & 2.00 & 2.52 & 2.69 & 2.79 \\
\hline
\end{tabular}

Source: authors' calculations 
so important. Nevertheless, the difference between the opinions of the 'Should be' and 'Is' groups is statistically significant only for the Czech Republic $(\mathrm{p}=0.0000)$.

The second difference between both groups of experts refers to the preparation of various scenarios for future solutions. The first group of experts ('Should be') gave on average higher results than the second group ('Is') both in Poland and the Czech Republic. However, the difference between the opinions of the 'Should be' and 'Is' groups is statistically significant only for the Czech Republic $(p=0.0005)$. In that area there is also a difference between the opinions of Polish and Czech management accountants (the 'Is' group), which is statistically significant at 10 per cent ( $p=0.0559$ ).

Experts from both countries gave ambiguous answers to questions about a management accountant's authority to affect resource allocation (e.g. make-or-buy, or decisions referring to sales structure and volume, decisions concerning the length of customer or distribution channels). However, Polish experts gave higher results for both the 'Should be' and 'Is' groups. The difference is statistically significant at 1 per cent ( $p=0.0001$ for the 'Should be' and $\mathrm{p}=0.0041$ for the 'Is' groups).

The exact results of that aspect of the study are shown in Tab. II.

\section{Specific Content of Management Accountants' Activities}

An analysis of the results for the next area of the research shows the great importance of management accounting in ensuring that companies target their information, i.e. in strategic, tactical and operational planning, which includes preparing, introducing and explaining forecasts and estimates, as well as in developing management accounting and internal reporting systems. The latter is slightly more important for Polish experts than for respondents from the Czech Republic; however, the difference is statistically significant, at 10 per cent, only for the 'Is' group $(p=0.0910)$.

All experts from the 'Should be' group emphasized the importance of the role of adequate information support for the acquisition of business resources (fixed assets, inventories, human resources etc.) and the management of business processes (research and development, purchasing, production, logistics, production, sales etc.); yet management accountants' participation in the development of the project management system and risk identification and management systems played a slightly less important role. As far as these three areas are concerned, the 'Is' group of management accountants from Poland rated those issues as more important than did the experts from the Czech Republic, and the differences are statistically significant at 10 per cent or less $(p=0.0002$, $\mathrm{p}=0.0106$ and $\mathrm{p}=0.0540$ respectively).

All the experts from Poland rated as more significant than did the Czech respondents the management accountants' participation in the development of organizational structures. The difference both in the 'Should be' and 'Is' group is statistically significant $(p=0.0302$ and $p=0.0000$ respectively).

The exact results of these aspects of the study are shown in Tab. III.

\section{Training Requirements}

The part of the questionnaires devoted to training requirements was based on the structure of requirements defined by IFAC International Education Standards (International Federation of Accountants [IFAC], 2003) and UNCTAD Revised Model Accounting Curriculum (United Nations Conference on Trade and Development [UNCTAD], 2011).

II: Areas of authority and responsibility

\begin{tabular}{|c|c|c|c|c|}
\hline \multirow{2}{*}{ Description } & \multicolumn{2}{|c|}{ 'Should be' } & \multicolumn{2}{|c|}{ 'Is' } \\
\hline & $\mathrm{CZK}$ & PL & CZK & PL \\
\hline $\begin{array}{l}\text { Coordination of activities connected with formulation of company objectives } \\
\text { and means of their fulfilment }\end{array}$ & 4.29 & 3.80 & 3.03 & 3.25 \\
\hline Preparation of scenarios of future solutions & 4.21 & 4.24 & 3.28 & 3.79 \\
\hline Development of an information system or its parts & 3.67 & 3.60 & 3.13 & 3.50 \\
\hline $\begin{array}{l}\text { Development of directives on pricing, costing, budgeting and management } \\
\text { accounting development and examination of adherence to them }\end{array}$ & 3.91 & 3.84 & 3.74 & 3.83 \\
\hline Communication of results attained to relevant management levels & 4.33 & 4.12 & 4.21 & 4.33 \\
\hline Explanation and interpretation of information rendered to managers & 4.54 & 4.28 & 4.37 & 4.63 \\
\hline Facilitation and support of communication between departments & 3.54 & 3.72 & 3.24 & 3.54 \\
\hline Decisions on resource allocation & 1.79 & 3.20 & 2.19 & 3.00 \\
\hline $\begin{array}{l}\text { Participation in the regulation of a company's financial management } \\
\text { development including the system of remuneration and motivation }\end{array}$ & 3.42 & 3.56 & 2.81 & 3.42 \\
\hline
\end{tabular}

Source: authors' calculations 
III: Specific content of management accountants' activities

\begin{tabular}{|c|c|c|c|c|}
\hline \multirow{2}{*}{ Description } & \multicolumn{2}{|c|}{ 'Should be' } & \multicolumn{2}{|c|}{ 'Is' } \\
\hline & $\mathrm{CZK}$ & PL & CZK & PL \\
\hline Strategic planning and budgeting & 4.29 & 4.44 & 4.13 & 4.21 \\
\hline Tactical planning and budgeting & 4.21 & 4.48 & 4.12 & 4.25 \\
\hline Operational planning and budgeting & 4.04 & 4.44 & 4.07 & 4.50 \\
\hline Expectation and forecast development & 4.29 & 4.00 & 4.46 & 4.38 \\
\hline $\begin{array}{l}\text { Participation in the development of management accounting and internal } \\
\text { reporting systems }\end{array}$ & 4.00 & 4.44 & 4.12 & 4.54 \\
\hline Participation in the development of the project management system & 3.54 & 3.56 & 2.65 & 3.63 \\
\hline $\begin{array}{l}\text { Participation in the development of the risk identification and management } \\
\text { system }\end{array}$ & 3.33 & 3.64 & 2.89 & 3.67 \\
\hline $\begin{array}{l}\text { Information support for acquisition of business resources and management of } \\
\text { processes (research and development, purchasing, production, logistics, sale etc.) }\end{array}$ & 4.17 & 3.96 & 3.44 & 4.04 \\
\hline $\begin{array}{l}\text { Development and enhancement of organizational structures including } \\
\text { follow-up activities }\end{array}$ & 2.88 & 3.56 & 2.33 & 3.83 \\
\hline
\end{tabular}

Source: authors' calculations

IV: Requirements for education

\begin{tabular}{|c|c|c|c|c|}
\hline \multirow{2}{*}{$\begin{array}{l}\text { Management accountant should be able to use knowledge from the following } \\
\text { fields: }\end{array}$} & \multicolumn{2}{|c|}{ 'Should be' } & \multicolumn{2}{|c|}{ 'Is' } \\
\hline & $\mathrm{CZK}$ & PL & $\mathrm{CZK}$ & PL \\
\hline Financial accounting and reporting & 4.71 & 4.64 & 4.59 & 4.67 \\
\hline Management accounting & 4.92 & 4.80 & 4.49 & 4.79 \\
\hline Corporate finance & 4.63 & 4.48 & 4.20 & 4.42 \\
\hline Taxation & 3.79 & 3.96 & 3.06 & 3.46 \\
\hline Business law & 3.17 & 3.72 & 2.46 & 3.29 \\
\hline Labour law & 2.83 & 3.32 & 2.25 & 2.75 \\
\hline Social and health insurance law & 2.75 & 3.20 & 2.33 & 2.54 \\
\hline Auditing & 3.42 & 4.04 & 3.03 & 3.83 \\
\hline Internal control systems & 3.96 & 4.20 & 3.53 & 4.21 \\
\hline Economics & 3.25 & 3.68 & 3.74 & 4.29 \\
\hline Management & 3.75 & 3.92 & 3.26 & 4.04 \\
\hline Business administration & 4.21 & 4.00 & 4.00 & 4.13 \\
\hline Marketing & 2.79 & 2.88 & 2.16 & 2.96 \\
\hline Quantitative methods (mathematics, statistics) & 3.58 & 4.16 & 3.21 & 4.25 \\
\hline International aspects of business & 2.88 & 3.52 & 2.73 & 3.50 \\
\hline Information and communication technology (ICT) & 3.75 & 3.68 & 3.27 & 3.63 \\
\hline
\end{tabular}

Source: authors' calculations

Nevertheless, other sources were also taken into account, e.g. the content and structure of the prequalification programmes of professional bodies such as the Chambers of Auditors of the Czech Republic and Poland, the Union of Accountants and the ACCA, syllabi of Master's degree specializations in accounting, controlling and corporate finance both at the Prague University of Economics and Business and Poznań University of Economics and Business.
Tab. IV shows that all groups of respondents have clearly confirmed the importance of a knowledge of financial accounting and reporting, management accounting, corporate finance and business administration. Conversely, according to the experts a knowledge of labour law, social and health insurance law and marketing is not so important for management accountants' activities. However, there are many areas that have been differently 
assessed by experts from Poland and the Czech Republic, e.g. auditing, quantitative methods and the international aspects of business are considered more important by experts from Poland than by respondents from the Czech Republic, both in the 'Should be' and the 'Is' groups, and the differences are statistically significant at 10 per cent or less (for auditing $\mathrm{p}=0.0625 / \mathrm{p}=0.0025$ ('Should be'/'Is'), for quantitative methods $\mathrm{p}=0.0540 / \mathrm{p}=0.000$, and for the international aspects of business, $p=0.0359 / p=0.0060$ ). There are also discrepancies in the opinions of Polish and Czech management accountants (the 'Is' group) concerning internal control systems, economics, management, marketing and ICT, the experts from Poland rating those areas higher than their Czech counterparts. The differences are statistically significant at 10 per cent or less $(p=0.0058, p=0.0147, p=0.0016$, $\mathrm{p}=0.0025$ and $\mathrm{p}=0.0870$ respectively).

\section{Requirements for ICT Competencies}

As seen in Tab. V., both groups of respondents agreed that the rapid development of ICT has altered the characteristics of management accountants' work. At the same time, it is expected that management accountants should take part in the development of their companies' ICT systems. These issues may be amplified by developments in Big Data analysis. Translated as "Business analytics, in the context of business organizations" (Acito and Khatri, 2014) this seems to render a management accountant's role and jurisdictional claim even more open to challenge.

Regarding more detailed areas of the study, both versions of the questionnaire were aimed at defining the role of management accounting pertaining to ICT. The main issue was whether management accountants (should) act only as ICT users or whether they (should) also take part in ICT development. The results state that management accountants are considered to be users of ICT rather than creators. Nevertheless, the result of the 'Is' group is significantly higher in the Czech Republic ( $p=0.0184)$. Management accountants are also considered to originate and verify both processing and user quality. The exact results for the Polish and Czech groups are differentiated; however, the only statistically significant difference refers to the Polish 'Is' group of management accountants' higher result for processing quality $(p=0.0032)$. According to both groups of respondents, management accountants should not serve (or do not serve) as the managers of ICT projects.

\section{Requirements for Professional Skills and Practical Experience}

As shown in Tab. VI., every group of experts from both countries considers communication and presentation skills and an ability to deal with other people and assert one's opinions as very important in management accountants' work. (Presentation skills were indicated by all groups as the most important requirement.) However, communication skills and presentation skills have been rated significantly higher by Polish management accountants (their 'Is' group) than by their Czech counterparts $(\mathrm{p}=0.0197$ and $\mathrm{p}=0.0015$ respectively).

For the Polish 'Should be' and 'Is' groups, managerial and organizational skills seem equally

$\mathrm{V}$ : ICT competencies

\begin{tabular}{|c|c|c|c|c|}
\hline \multirow{2}{*}{ In the area of ICT a management accountant acts especially as: } & \multicolumn{2}{|c|}{ 'Should be' } & \multicolumn{2}{|c|}{ 'Is' } \\
\hline & $\mathrm{CZK}$ & PL & $\mathrm{CZK}$ & PL \\
\hline User (with stress on areas he/she uses) & 4.26 & 4.16 & 4.48 & 3.96 \\
\hline Creator (with stress on areas he/she uses) & 3.30 & 3.28 & 3.25 & 3.67 \\
\hline Originator or verifier of processing quality & 3.70 & 3.76 & 3.13 & 3.92 \\
\hline Originator or verifier of user quality & 3.91 & 3.52 & 3.51 & 3.54 \\
\hline Manager of ICT projects or their parts & 2.71 & 2.64 & 2.91 & 3.04 \\
\hline
\end{tabular}

Source: authors' calculations

VI: Requirements for professional skills and practical experience

\begin{tabular}{|c|c|c|c|c|}
\hline \multirow{2}{*}{ It is important for a management accountant to develop especially: } & \multicolumn{2}{|c|}{ 'Should be' } & \multicolumn{2}{|c|}{ 'Is' } \\
\hline & $\mathrm{CZK}$ & PL & $\mathrm{CZK}$ & PL \\
\hline Communication skills & 4.38 & 4.28 & 4.10 & 4.46 \\
\hline Ability to deal with people and assert his/her opinions & 4.46 & 4.20 & 4.06 & 4.08 \\
\hline Presentation skills & 4.58 & 4.52 & 4.22 & 4.75 \\
\hline Managerial and organizational skills & 3.63 & 4.16 & 3.79 & 4.04 \\
\hline Language knowledge including ability to use it & 3.57 & 3.88 & 3.63 & 3.71 \\
\hline
\end{tabular}

Source: authors' calculations 
important, but slightly less so for both Czech groups. The difference between the Polish and Czech 'Should be' groups' opinions is statistically significant at 5 per cent $(p=0.0176)$, but is not significant for the 'Is' group.

Every group of experts indicates language skills as the least important.

\section{Management Accountants' Role in Ethical Aspects of Business}

Moving on to the next area of the research (Tab. VII), according to both groups of experts, both in the Czech Republic and Poland, it is important for a company to define, enhance, support and effectively communicate the ethical principles and rules of business as well as to incorporate them into company standards, codes and guidelines. This area was underplayed for a long time, especially in business practice, some symptoms of which can be seen in the 'Is' group in the case of the incorporation of principles into the Czech Republic.

The research also indicates a relatively low level of management accountants' participation (according to every group of respondents in both countries) in the development, inspection and fulfilment of companies' ethical standards, codes and guidelines. Upon these points opinions diverged within the 'Is' group, being rated relatively low in the Czech Republic and higher in Poland, although the only statistically significant difference refers to the participation of management accountants in the development of ethical standards, codes and guidelines $(p=0.0010)$.

Overall, the management accountants' role in the enforcement of ethical principles, standards and guidelines seems to be unsatisfactory.

\section{Human Resources Management}

The next aspect of the research concentrates on the recruitment of the right candidates for management accounting roles and on the problem of management accountants' ongoing professional development.

Regarding the problem of candidate selection, both groups of experts from both countries generally agreed regarding most of the statements. Every group confirmed that training, practical experience, an ability to deal with people, an appropriate personality profile and communication skills are crucial features for a management accountants' role. The last two factors cause the biggest differences in opinions in the 'Is' group they are relatively much more important in Poland. (The differences are statistically significant at 1 per cent: $p=0.0003$ and $p=0.0001$ respectively.)

ICT competencies play a slightly less important role, especially for both groups of respondents in the Czech Republic.

Every groups paid less attention to languages. It is worth noting that language skills are more appreciated in practice in Poland.

The exact results regarding these points are shown in Tab. VIII.

As far as management accountants' professional development is concerned, every group of experts from the Czech Republic and Poland thinks that ongoing professional development is the important key to the quality of management accountants' work.

The study shows that management should enable management accountants to participate in professional development and should verify whether management accountants are enhancing their professional competencies. The responses in the 'Should be' group indicated that this was held to be more important in the Czech Republic than Poland, although only the difference in responses to the first of the above issues is statistically significant, with $p=0.0251$. The experts from the 'Is' group, especially in the Czech Republic, generally pay less attention to such factors. The biggest difference in opinion in business practice concerns the verification of competency development, which seems not to be

VII: Management accountants' role in ethical aspects of business

\begin{tabular}{|c|c|c|c|c|}
\hline \multirow{2}{*}{ Description } & \multicolumn{2}{|c|}{ 'Should be' } & \multicolumn{2}{|c|}{ 'Is' } \\
\hline & $\mathrm{CZK}$ & PL & $\mathrm{CZK}$ & PL \\
\hline $\begin{array}{l}\text { It is important for a company to define, enhance, support and communicate } \\
\text { effectively the ethical principles and rules of business }\end{array}$ & 4.58 & 4.20 & 4.13 & 4.29 \\
\hline $\begin{array}{l}\text { These principles and rules are explicitly incorporated into company standards, } \\
\text { codes and guidelines }\end{array}$ & 4.50 & 4.12 & 3.90 & 4.21 \\
\hline $\begin{array}{l}\text { A management accountant participates in the development of ethical company } \\
\text { standards, codes and guidelines }\end{array}$ & 3.63 & 3.48 & 2.49 & 3.42 \\
\hline $\begin{array}{l}\text { In the scope of his/her authorities and responsibilities, the management } \\
\text { accountant participates in the inspection of how these standards, codes and } \\
\text { guidelines are fulfilled }\end{array}$ & 3.38 & 3.72 & 3.16 & 3.67 \\
\hline $\begin{array}{l}\text { A management accountant serves as an informal authority in the fulfilment of } \\
\text { these standards, codes and guidelines - in the internal company environment } \\
\text { as well as externally }\end{array}$ & 3.38 & 3.28 & 2.68 & 3.08 \\
\hline
\end{tabular}

Source: authors' calculations 
VIII: Selection of potential candidates for a management accountant position

\begin{tabular}{|c|c|c|c|c|}
\hline $\begin{array}{l}\text { In the process of potential management accountant selection it is important } \\
\text { to take into consideration: }\end{array}$ & $\mathrm{CZK}$ & PL & $\mathrm{CZK}$ & PL \\
\hline Present practical experience & 4.38 & 4.56 & 4.50 & 4.71 \\
\hline Ability to deal with people and personality profile & 4.08 & 4.32 & 4.06 & 4.63 \\
\hline ICT competencies & 3.67 & 3.96 & 3.75 & 3.92 \\
\hline Language knowledge & 3.57 & 3.52 & 3.44 & 3.83 \\
\hline
\end{tabular}

Source: authors' calculations

IX: Conditions of management accountants' professional development

\begin{tabular}{|c|c|c|c|c|}
\hline \multirow{2}{*}{ Management accountants' professional development } & \multicolumn{2}{|c|}{ 'Should be’ } & \multicolumn{2}{|c|}{ 'Is' } \\
\hline & CZK & PL & $\mathrm{CZK}$ & PL \\
\hline $\begin{array}{l}\text { Management accounting department consists of a stable team of experts who } \\
\text { do not change very often }\end{array}$ & 3.75 & 3.32 & 4.11 & 4.13 \\
\hline $\begin{array}{l}\text { In comparison with employees operating at the same organizational level, } \\
\text { management accountants are paid above average }\end{array}$ & 3.30 & 4.08 & 3.57 & 3.71 \\
\hline $\begin{array}{l}\text { Continuing professional development is quite important for the quality of the } \\
\text { management accountants' work }\end{array}$ & 4.58 & 4.40 & 4.43 & 4.42 \\
\hline $\begin{array}{l}\text { Company management enables its management accountants to continue their } \\
\text { professional development }\end{array}$ & 4.63 & 3.92 & 3.75 & 4.13 \\
\hline $\begin{array}{l}\text { Company management verifies whether management accountants enhance } \\
\text { their professional competence }\end{array}$ & 4.17 & 3.64 & 2.76 & 3.54 \\
\hline
\end{tabular}

Source: authors' calculations

considered so essential in the Czech Republic. (The difference between the two countries is statistically significant at 1 per cent, $p=0.0062$.)

Every group of experts confirms that the salary of management accountants should be/is slightly higher than the remuneration of other employees from the same organizational level. The biggest difference in opinions occurs in the 'Should be' group, where this factor was rated much higher in Poland (the difference between the countries being statistically significant at 1 per cent, $\mathrm{p}=0.0006$ ).

What is surprising experts from the 'Should be' group in both countries (but especially in Poland) find the stability of the management accounting team not terribly important. On the other hand, practice (both in the Czech Republic and Poland) shows that in firms there tends to be little rotation in that team.

Exact results are shown in Tab. IX.

\section{Quality Assurance of Management Accountants' Activities}

In the next area of the study it is worth noting that respondents from the "Should be" group both in the Czech Republic and Poland generally agree with the necessity of evaluating all aspects of management accountants' work.
This differs among the "Is" group. The respondents from the Czech Republic paid much less attention than those in Poland to all aspects of quality assurance. The differences between both countries are statistically significant at 1 per cent for information relevance $(p=0.0004)$, timeliness of rendered information ( $p=0.0012$ ), formal level of rendered information ( $p=0.0000$ ), neutrality and objectivity of information $(p=0.0005)$ and information comparability and consistency $(p=0.0026)$. The difference for the correctness of input data was not statistically significant. Information flexibility was rated relatively low in both countries in this group.

Regarding the above issues, it can be stated that the development of quality standards could improve the general awareness of the best means for assuring increases in the quality of the management accountants' profession for the future and flag the importance of such an improvement. The results presented in this section could be considered as an initial guide for quality standards development.

The exact results of these aspects of the study are shown in Tab. X. 
X: Quality assurance of management accountants' work

\begin{tabular}{|c|c|c|c|c|}
\hline \multirow{2}{*}{ Management accountant quality assurance includes: } & \multicolumn{2}{|c|}{ 'Should be' } & \multicolumn{2}{|c|}{ 'Is' } \\
\hline & CZK & PL & CZK & PL \\
\hline Correctness of input data & 4.00 & 3.96 & 3.85 & 4.38 \\
\hline Information relevance & 4.67 & 4.28 & 4.04 & 4.67 \\
\hline Timeliness of rendered information & 4.52 & 4.48 & 3.86 & 4.54 \\
\hline Formal level of rendered information & 4.17 & 4.36 & 3.54 & 4.75 \\
\hline Neutrality and objectivity of information & 4.71 & 4.44 & 3.69 & 4.46 \\
\hline Information flexibility & 4.09 & 3.92 & 3.70 & 3.88 \\
\hline Information comparability and consistency & 4.67 & 4.40 & 4.15 & 4.79 \\
\hline
\end{tabular}

Source: authors' calculations

\section{CONCLUSION}

The results of the project, although based on modest number of responses and limited to Czech Republic and Poland only, are very interesting and have already brought inspirations both in the area of conceptual ideas as well as the empirical research outcomes.

As presented in this paper, both groups of respondents in both countries have their own specific characteristics, but also share some common qualities and requirements in respect to management accountants' competences.

The most important of them are the following:

- management accountants must serve not only as providers of information support but rather as the managers' partners;

- nevertheless, in their role of "economic conscience of a company" they must be responsible for the quality, availability and transparency of the data provided and transferred to managers, as well as for their subsequent processing into the output information used in managerial control;

- management accountants should be equipped with sufficient authority and responsibility in the areas in which they serve as communicators, developers and experts in coordination and scenario analysis, as well as the specialists which participate in the regulation and support of the company's financial management development including the system of remuneration and motivation;

- management accountants should play important role in ensuring that companies target their information, i.e. in strategic, tactical and operational planning, which includes preparing, introducing and explaining forecasts and estimates, as well as in internal reporting system development;

- regarding the professional competence development, all groups of respondents have clearly confirmed the importance of knowledge of financial accounting, management accounting, reporting, corporate finance and business administration and considered communication and presentation skills and an ability to deal with other people and assert one's opinions as very important in management accountants' work;

- these features should be taken into consideration in the phase of candidate selections as well as in the long-life building of professional competence of management accountants; the study shows that management should not enable management accountants to build their professional development only but also should verify whether they enhance their professional competencies continuously;

- regarding the role of management accountants in ICT systems development, the results of the study show that they are considered to be more users of ICT rather than their creators; nevertheless, they are also considered to originate and verify both processing and user quality of these systems;

- moving on to the next area of the research, according to both groups of experts in both countries it is important for a companies to define, enhance, support and effectively communicate the ethical principles and rules of business as well as to incorporate them into company standards, codes and guidelines including the role of management accountants in their fulfilment; this area has been underestimated for a long time, especially in business practice of both countries.

The results of the study stress a significant role that management accountants play in modern companies and suggest the necessity of developing standards and requirements for this position. Having this in mind, conducting analogous research of management accountants' professional 
competences in other countries and extending the spectrum of companies and business professionals included in the study seem to be interesting and important for the future development of the quality system of companies' management.

Acknowledgements

This paper is an outcome of a project "Analysis of relationship between strategic management accounting and corporate management and performance” supported by the Grant No. F1/71/2017 (internal number IG107027) - Internal Grant Agency of the University of Economics, Prague.

\section{REFERENCES}

ACITO, F. and KHATRI, V. 2014. Business analytics: Why now and what next? Business Horizons, 57(5): 565-570.

ASSOCIATION OF CHARTERED CERTIFIED ACCOUNTANTS \& BEIJING NATIONAL ACCOUNTING INSTITUTES. 2014. Investigation Report: Management Accounting Practice in Chinese Firms. Association of Chartered Certified Accountants \& Beijing National Accounting Institutes.

BIEŃKOWSKA, A., KRAL, Z. and ZABŁOCKA-KLUCZKA, A. 2014. Organizational solutions of controlling in network organizations [in Polish: Rozwiązania organizacyjne controllingu w organizacjach sieciowych]. In: NOWAK, E. and NIEPLOWICZ, M. (Eds.) Accounting and controlling [in Polish: Rachunkowość a controlling]. Research Papers of Wrocław University of Economics No. 344, pp. 53-69.

BURNS, J. and BALDVINSDOTTIR, G. 2005. An institutional perspective of accountants' new roles: The interplay of contradictions and praxis. European Accounting Review, 14(4): 725-757.

BURNS, J. and YAZDIFAR, H. 2001. Trick or treats? Financial Management, 30(1): 33-35.

CHARTERED INSTITUTE OF MANAGEMENT ACCOUNTANTS. 2008. Improving Decision Making in Organizations: The Opportunity to Reinvent Finance Business Partners. London: CIMA.

CHARTERED INSTITUTE OF MANAGEMENT ACCOUNTANTS. 2009. Management Accounting Tools for Today and Tomorrow. London: CIMA.

FOREMNA-PILARSKA, M. 2015. Controlling. Tools and structures [in Polish: Controlling. Narzędzia i struktury]. Warszawa: PWE.

GMIŃSKA, R. 2014. Behavioural aspects in management accounting [in Polish: Aspekty behawioralne w rachunkowości zarządczej]. In: NOWAK, E. and NIEPLOWICZ, M. (Eds.). Accounting and controlling [in Polish: Rachunkowość a controlling]. Research Papers of Wrocław University of Economics No. 344, pp. 185-193.

GORETZKI, L., STRAUSS, E. and WEBER, J. 2013. An institutional perspective on the changes in management accountants' professional role. Managements Accounting Research, 24(1): 41-63.

GRANDLUND, M. and LUKKA, K. 1998. Towards increasing business orientation: Finnish management accountants in a changing cultural context. Management Accounting Research, 9: 185-211.

HOPPER, T. 1980. Role conflicts of management accountants and their position within organization structures. Accounting Organization and Society, 31(2): 129-155.

HORVÁTH, P. 2006. The management accounting concept. The way to an effective management accounting system [in German: Das Controllingkonzept. Der Weg zu einem wirkungsvollen Controllingsystem]. München: DTV Verlag Valen Beck.

INTERNATIONAL FEDERATION OF ACCOUNTANTS. 2003. International Education Standards for Professional Accountants. New York: IFA.

JABLONSKY, F. S., KEATING, P. J. and HEIAN, J. B. 2004. Business Advocate or Corporate Policeman. New York: Financial Research Foundation.

JANCZYK-STRZAŁA, E. 2008. Controlling in manufacturing companies [in Polish: Controlling w przedsiębiorstwach produkcyjnych]. Warszawa: CeDeWu.

JANIK, W. and PAŹDZIOR, M. 2012. Management accounting and controlling [in Polish: Rachunkowość zarządcza i controlling]. Lublin: Politechnika Lubelska.

JARUGA, A., NOWAK, W. and SZYCHTA, A. 1999. Management accounting. Concepts and applications Rachunkowość zarządcza [in Polish: Koncepcje i zastosowania]. Łódź: Absolwent.

JÄRVENPÄÄ, M. 2007. Making business partners: A case study on how management accounting was changed. European Accounting Review, 16(1): 99-142.

KAPLAN, R. and ANDERSON, S. 2007. Time-Driven Activity-Based Costing. A Simpler and More Powerful Path to Higher Profits. Harvard Business School Press, Polish edition 2008. Warszawa: PWN.

KES, Z. 2013. Organizational aspects of controlling [in Polish: Organizacyjne aspekty controllingu]. In: NOWAK, E. (Ed.). Controlling for managers [in Polish: Controlling dla menedżerów]. Warszawa: CeDeWu. 
KRÁL, B. and ŠOLJAKOVÁ, L. 2014. Requirements on controllers in the Czech Republic. An empirical study. Zeszyty Teoretyczne Rachunkowości, 99: 151-175.

KRÁL, B. and ŠOLJAKOVÁ, L. 2015. Professional competence requirements on controllers in the Czech Republic: An empirical study. In: International conference Finance and performance of firms in science, education and practice. Tomas Bata University in Zlín, April 23-24, 2015.

KRÁL, B. and ŠOLJAKOVÁ, L. 2016. Development of controllers' professional competence: the case of the Czech Republic. Economics \& Sociology, 9(1): 86-100.

KRÁL, B., MIKOŁAJEWICZ, G., NOWICKI, J. and ŠOLJAKOVÁ, L. 2017. Professional Competences of Controllers: The Case of Poland. European Financial and Accounting Journal, 12(2): 17-40.

MARCINIAK, S. 2008. Controlling. Theory, applications [in Polish: Controlling. Teoria, zastosowania]. Warszawa: Difin.

NOWAK, M. 2013. Work in controlling and undertaken group roles. Analysis of empirical study [in Polish: Praca w controllingu a przybierane role grupowe. Analiza wyników badań empirycznych]. In: NOWAK, E. and NIEPLOWICZ, M. (Ed.). Cost accounting and management control systems [in Polish: Systemy rachunku kosztów i kontroli zarządczej]. Research Papers of Wrocław University of Economics No. 289, pp. 438-448.

NOWAK, M. 2014a. Male and Female Controllers. Between Controlling and Gender Studies. In: NITA, B. (Ed.). Performance Measurement and Management. Research Papers of Wrocław University of Economics No. 345, pp. 86-93.

NOWAK, M. 2014b. Importance of time perspectives in controlling - theoretical definitions vs. psychological characteristics of controllers [in Polish: Znaczenie wymiarów czasu w controllingu - definicje teoretyczne a psychologiczna charakterystyka controllerów]. In: NOWAK, E. and NIEPLOWICZ, M. (Ed.). Accounting and controlling [in Polish: Rachunkowość a controlling]. Research Papers of Wrocław University of Economics No. 344, pp. 185-193.

PIERCE, B. and O'DEA, T. 2003. Management accounting information and the needs of managers: perceptions of managers and accountants compared. British Accounting Review, 35(3): 257-290.

SIERPIŃSKA, M. and NIEDBAŁA, B. 2003. Operational controlling in a company [in Polish: Controlling operacyjny w przedsiębiorstwie]. Warszawa: PWN.

STEINKE, K.-H., SCHUlZE, M., BERLIN, S., STEHLE, A. and GEORG, J. 2014. Green Controlling. Internationaler Controller Verein. Freiburg: Haufe Verlag.

SZYCHTA, A. 2011. Management accounting as a professional activity in the context of foreign experiences [in Polish: Rachunkowość zarządcza jako działalność zawodowa w kontekście doświadczeń zagranicznych]. Zeszyty Teoretyczne Rachunkowości, 62(118): 289-312.

UNITED NATIONS CONFERENCE ON TRADE AND DEVELOPMENT. 2011. Model Accounting Curriculum (Revised). Geneva: UNCTAD.

YASIN, M. M., BAYES, P. E. and CZUCHRY, A. J. 2005. Changing role of accounting in supporting the quality and customer goals of organizations: an open system perspectives. International Journal of Management, 22(3): 322-331.

ZRALÝ, M. 2007. Integration Concept of Management Control and its Contribution to Performance Management. In: Proceedings of EIASM $4^{\text {th }}$ Conference on Performance Measurement and Management Control. Nice, 9/2007.

Contact information

Libuše Šoljaková: soljak@vse.cz (corresponding author)

Bohumil Král:kral@vse.cz

Grzegorz Mikołajewicz: Grzegorz.Mikolajewicz@ue.poznan.pl

Jarosław Nowicki: Jaroslaw.Nowicki@ue.poznan.pl 


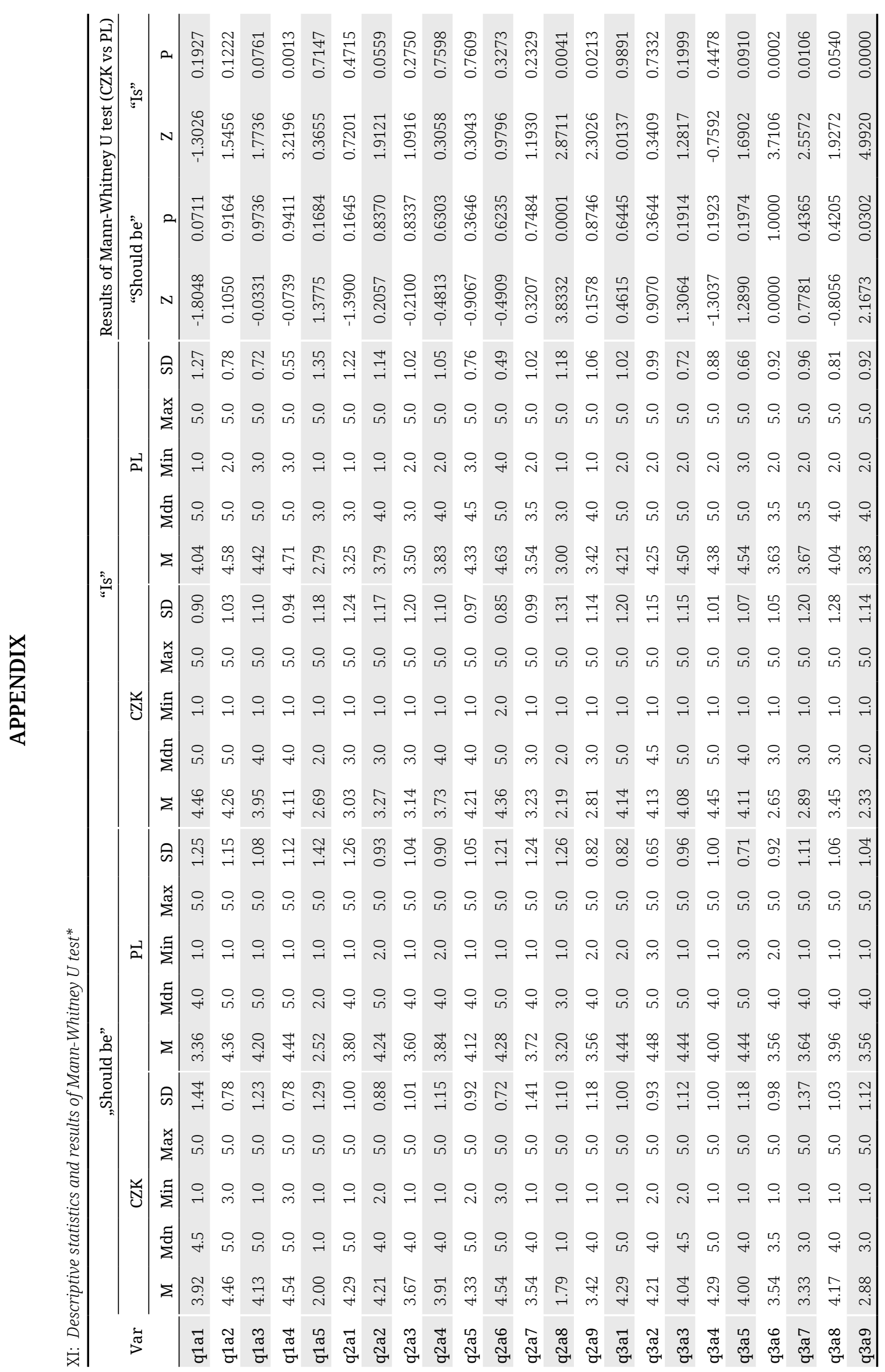




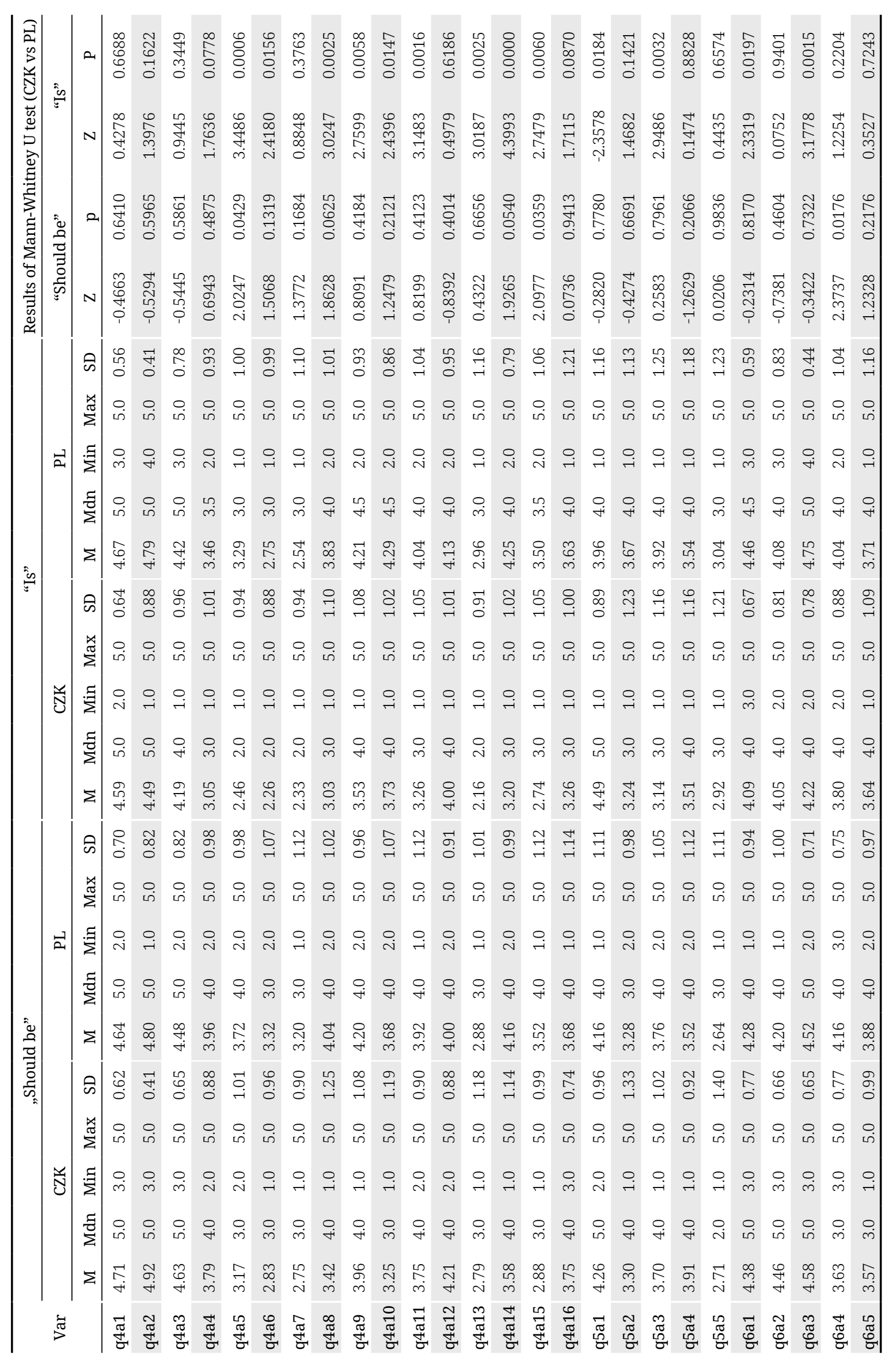




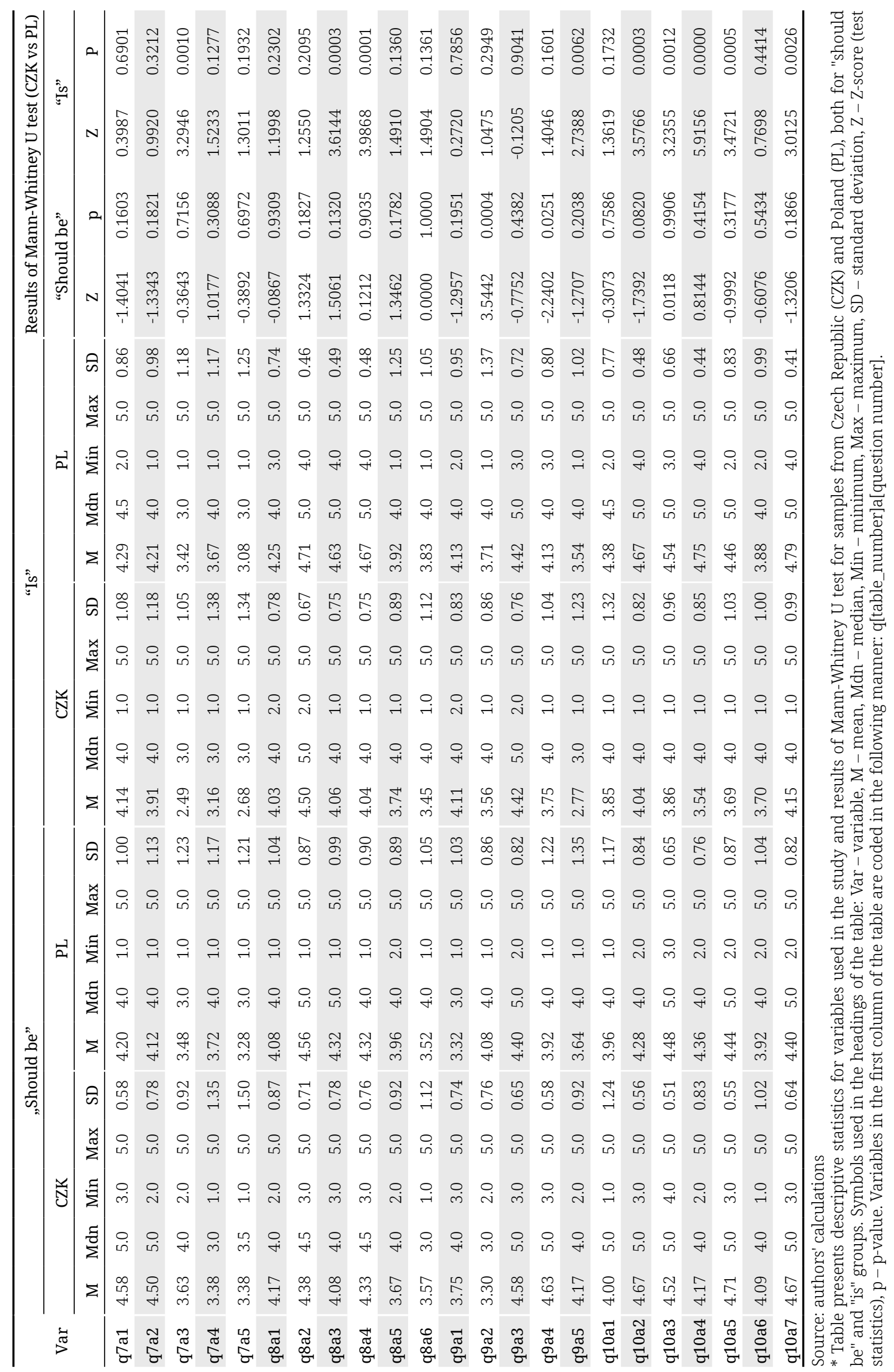


